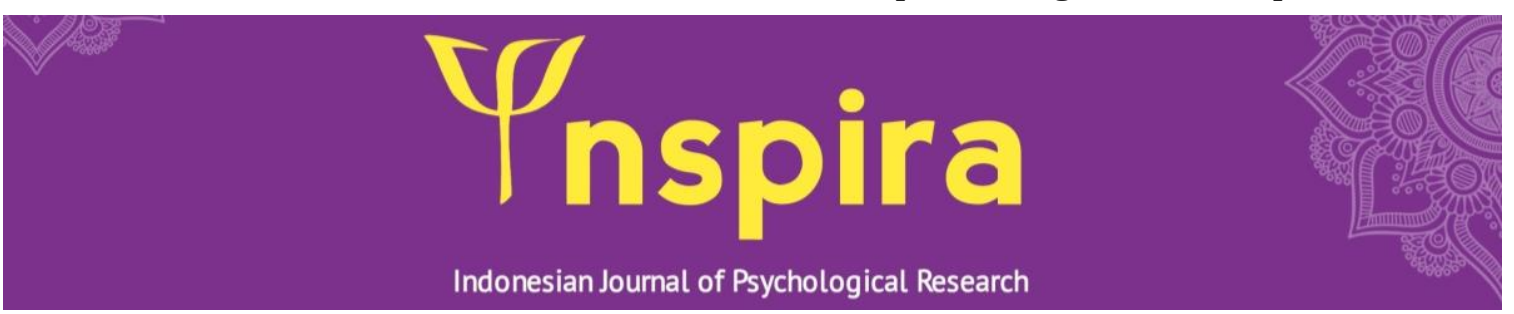

\title{
Self-acceptance as a predictor of self-esteem in victims of body shaming
}

Nur Afni Safarina ${ }^{1 凶}$, Maulayani $^{2}$

1,2 Department of Psychology, Universitas Malikussaleh, Aceh, Indonesia

\section{${ }^{\otimes}$ Corresponding author:}

Nur Afni Safarina (email: nurafni.safarina@unimal.ac.id)

Abstract - This study aimed to determine and analyze the influence of self-acceptance on self-esteem on the victim of body shaming in SMAN 1 Lhokseumawe. The approach of this study was a quantitative correlational method. The samples of this study were 75 students of SMAN 1 Lhokseumawe, and ever be the victim of body shaming. This study uses the purposive sampling technique. This study's data collection methods were used two scales, namely scale of self-acceptance and selfesteem scale. Then, the data were analyzed by using simple linear regression. The result of this study indicates a correlation between selfacceptance and self-esteem variables. The constant value shows that the coefficient is positive and has a positive or consistent correlation. There is an influence between self-acceptance of self-esteem by using formula $\mathrm{t}$-table and t-count to test the hypothesis, and the result is the same. The initial hypothesis is acceptable. That is mean the hypothesis in this study can be accepted.

\section{Article History:}

Received: May 01, 2021

Revised: June 01, 2021

Accepted: June 26, 2021

Published: June 30, 2021

\section{Keyword:}

body shaming; selfacceptance; self-esteem; high school students

How to cite (APA $7^{\text {th }}$ Edition)

Safarina, N. A. \& Maulayani, M. (2021). Self-acceptance as a predictor of self-esteem in victims of body shaming. INSPIRA: Indonesian Journal of Psychological Research, 2(1), 5-11. https://doi.org/10.32505/inspira.v2i1.2946

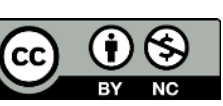

This is an open-access article distributed under the Creative Commons Attribution License, which permits unrestricted use, distribution, and reproduction in any medium provided the original work is properly cited. This is enabled under the terms of attribution and noncommercial usage of the material (C2021 by Nur Afni Safarina \& Maulayani. 


\section{INTRODUCTION}

Adolescence is a transition from childhood to adulthood, and it can be said that adolescence is a transitional period that bridges childhood to adulthood. According to Papalia, Diana, Old, \& Feldman (2011), adolescence is a period of development from childhood to adulthood that begins at age ten and ends at the early 20 years. Teenagers usually interact more with the surrounding environment, be it school or other social environments, than interacting with family members or parents. In adolescence, individuals will experience changes in extensive social interactions and increased social skills resulting from the interaction of broad peers (Febriani, 2020). According to Hurlock (2002) in Hidayati (2016), adolescence is a period of storms and pressures that cause adolescents to experience an increasing emotional condition due to physical and psychic changes. In adolescence, there are many changes in a person, including changes in the physical and socio-emotional aspects. Changes that occur in the physical aspect are usually a change in body shape, and in the socio-emotional aspects of adolescents tend to be more sensitive such as easy crying, anxiety, and even frustration (Kusmiran, 2014).

Some physical changes in adolescence result in teenagers feeling less confident with their appearance (Sakinah, 2018). Physical changes experienced by teenagers also make teenagers often pay attention to themselves and make judgments about their physical appearance (Solistiawati \&Novendawati, 2015). According to society today, the ideal body shape is used as a guide by teenagers to assess their body shape and the body shape of others around it (Rusminingsih, Suciana, \&Wahyuningsih, 2020). In adolescence, they tend to interact more with their peers. When teenagers have more interactions with peers, it presents new problems for adolescents. Peers use physical appearance more often as a mockery of other individuals if the individual looks not up to the standard (Widiasti, 2016). Such behavior is called body shaming.

Body shaming is an action performed by a person by criticizing body shapes such as mocking or denouncing weight, skin color, body shape, and height (Rahayu, 2019). According to Wardhana, Kiranantia, Tantiani, \&Puspitasari (2019), body shamming is the behavior of criticizing commenting on the physical body itself or others negatively. Body shaming is a despicable act in which the culprit insults or taunts others for physical deprivation. According to Vargas (2015), the characteristics of body shamming behavior include criticizing the shape of his appearance and comparing it to others, criticizing the body shape of others around him, giving criticism without the knowledge of the person who is criticized with reproach on the body shape of the people around him. In adolescence, this is what happens a lot. Whether it is obtained from peers or others, body shamming can happen in cyberspace through social media or in the real world. Teenagers who are victims of body shamming tend not to accept their physical condition. Victims of body shaming will undoubtedly decrease their attitude of self-acceptance towards themselves, where self-acceptance has a close relationship with one's physical acceptance (Ridha, 2012).

According to Chaplin (2012), self-acceptance is one's self-satisfaction, understanding one's qualities and talents, and recognizing one's limitations. Self-acceptance is shown by recognizing the advantages that he has and accepting the shortcomings that exist in him without blaming those around him. Teenagers who can accept themselves will be positive about everything or problems in their lives (Rinmalae, Regaletha, Benu, 2019). 
When a person has good self-acceptance, then he will also have good self-esteem. This is following what Ryff stated that when a person accepts himself, he will have a positive attitude towards himself, acknowledge his weaknesses and strengths, and respect himself (Wangge \&Hartini, 2013). Self-esteem is an individual's assessment of himself, whether it is positive or negative. According to Oktaviani (2019), self-esteem is an individual evaluation of himself by recognizing or not the ability possessed and the appreciation and acceptance of others as a comparison between himself and others. The decline in self-esteem is often in adolescence, where the teenager feels he does not have an ideal body shape and does not have the advantages that can be used as capital in his association (Syafrizaldi \&Pratiwi, 2020). Many studies have suggested that decreased self-esteem frequently occurs in adolescence (Wahyuni \&Aurellia, 2021). Decreased self-esteem in adolescents can occur due to problems experienced and emotional management skills in adolescents who are not stable. One of the problems in adolescence and related to self-esteem is self-acceptance related to body shamming performed by peers and people in the surrounding environment.

Therefore, in this study, researchers will especially see how adolescent self-acceptance is the victim of body shaming at SMA Negeri 1 Lhokseumawe. This research was conducted because in high school students in Lhokseumawe, especially SMA Negeri 1 Lhokseumawe often occur abuse, one form of bully performed is body shamming by physically insulting friends. The difference between this study and other studies is that this study also looked at the correlation between self-acceptance and self-esteem in victims of body shaming, where previously, many studies only looked at aspects of self-acceptance or self-esteem. Therefore, the purpose of this study is to see how the influence of self-acceptance on the self-esteem of students at SMA Negeri 1 Lhokseumawe who experience body shamming.

\section{RESEARCH METHOD}

This type of research is nonexperimental quantitative research with a correlational research design. The primary purpose of the research with correlational design is to describe the relationship between existing variables and determine the relationship between dependent and independent variables (Heryana, 2020). The free variable in this study was self-acceptance, whereas the bound variable was self-esteem.

This research was conducted at SMA Negeri 1 Lhokseumawe, held for one month in November 2019. The population in this study was all students of SMA Negeri 1 Lhokseumawe. The samples in this study numbered 75 students that were chosen by using purposive sampling techniques. The characteristics of the population taken are students who attended SMA Negeri 1 Lhokseumawe and had been victims of body shaming. This study uses a data collection method in the form of a psychological scale: 1) the scale of self-acceptance used in this study compiled by Tika Pratiwi Andani (2018). The scale of self-acceptance is based on aspects of self-acceptance expressed by Powel, namely physical acceptance, intellectual acceptance, acceptance of selflimitations, acceptance of feelings or emotions and acceptance of personality, and 2) The selfesteem scale used in this study was compiled by Tika Pratiwi Andani (2018) based on the scalemaking component of the Rosenberg Self Esteem Scale (1965) with two dimensions namely confidence and the ability to display yourself openly in front of others. 


\section{RESULT}

Normality test is a test to measure whether the population of data owned is a normal distribution to be used in parametric statistics (inferential statistics). Data is declared normally distributed when it has a significance value more significant than 0,05 (Priyatno, 2011). The normality test in this study was to use the Kolmogorov Smirnov test.

Table 1 One-sample Kolmogorov-Smirnov test

\begin{tabular}{cc}
\hline Variable & p-value \\
\hline Self-acceptance & 0,035 \\
\hline Self-esteem & $<0,001$ \\
\hline
\end{tabular}

Based on the trials that have been conducted in the form of normal self-acceptance variables, while self-esteem variables are not normal.

The linearity test aims to find out if two variables are significantly related or not. Linearity test on SPSS is used Test for Linearity with significance level 0,05. Two variables have a linear relationship when the significant value in linearity is minor than 0,05 (Priyatno, 2011). The linearity test in this study aims to see if there is a variable relationship of self-acceptance with self-esteem in victims of body shaming.

Based on the test, an $\mathrm{F}$ value of 38,017 with $\mathrm{p}<0.001$ was produced. Because the $\mathrm{p}$-value $<0.05$, the relationship between self-acceptance and self-esteem variables is linear or has a linear degree. So it can be concluded that there is a linear influence between self-acceptance and selfesteem in victims of body shamming students at SMA Negeri 1 Lhokseumawe.

Based on a simple linear regression analysis used to determine the influence between dependent and independent variables, generate data in the form of the following table:

Table 2 Simple linear regression test

\begin{tabular}{cccc}
\hline Constant value & Coefficient of Regression & t-count & t-table \\
\hline 5,631 & 0,228 & 5,487 & 2,041
\end{tabular}

Based on the table, it can be known that the constant value of 5,631and the value of the variable regression coefficient of self-acceptance of 0.228 , as well as the coefficient of positive value, which means that the higher the self-acceptance, the more self-esteem increases the student.\&n; Then, simple linear regression analysis also produced a t-count to test the hypothesis. Based on the above output, it can be seen the calculated t value of 5,487 and the ttable value of this result of 2,041. This indicates that the calculated $\mathrm{t}$ value $<\mathrm{t}$ table $(2,041<$ $5,487)$. This shows that $\mathrm{H}_{0}$ was rejected, which means that there is an influence between selfesteem and self-esteem of SMA Negeri 1 Lhokseumawe students who are victims of body shaming. Then, hypothesis testing can also be done by looking at the value of significance. If the significance value $>0,05$, then $\mathrm{H}_{0}$ is accepted. On the contrary, if the significance value $<0,05$, then $\mathrm{H}_{0}$ is rejected. It can be seen that the significance value was $0.00<0,05$. It means $\mathrm{H}_{0}$ was rejected, and this study proves that there is an influence between the two variables that are examined. 


\section{DISCUSSION}

The purpose of this study is to find out the influence of self-esteem on self-acceptance in victims of body shamming students at SMA Negeri 1 Lhokseumawe. Based on the research process that has been done, running smoothly, and by the plan that has been compiled. This study uses a quantitative method with a questionnaire to collect data that corresponds to each variable. Then also this study, there is a hypothesis or temporary conjecture before the research was conducted, namely the influence between self-acceptance and self-esteem in students who are victims of body shaming.

Based on the results of several tests that have been done before, it can be seen that these variables of self-acceptance and price have a linear pattern of interrelationship, which means that these variables are interconnected and aligned, suitable for linking between one and another. This is because self-acceptance is a factor in the formation of one's self-esteem. A simple linear regression test results in a positive value coefficient, which means that the higher the selfacceptance, the more self-esteem the student.

Based on the hypothesis testing mentioned earlier, and the results of the initial hypothesis are correct, there is an influence between self-acceptance and self-esteem in students victims of body shaming behavior. It also shows that by having good self-acceptance, one can appreciate him more, even though he is a victim of bad behavior, namely body shamming.

Body shamming behavior itself is considered a weapon that can interfere with the psychology of a person, especially teenagers who are in a time known as unstable. However, in this study, they proved that they have good self-esteem. Self-esteem can increase with acceptance as one of the factors. Self-acceptance is one of the determining factors of the formation of one's self-esteem, especially in adolescents. Adolescence is the time when a person tries to find his or her identity. When he can accept himself well, he is also able to appreciate himself well without having to be appreciated or loved by others first. In this study, it can be seen that students of SMA Negeri 1 Lhokseumawe proved that self-acceptance affects one's self-esteem. When he cannot accept himself well, it can also cause him to feel unwelcome, helpless, incapable of doing what he wants, unacceptable to a group, and other negative thoughts. When a person feels that way, then that is where his self-esteem begins to falter. This is based on not maximal selfacceptance.

Self-acceptance is a variable that influences self-esteem in this study. In line with Maslow's theory, he explained that in the hierarchy of human needs, self-esteem is the fourth need that must be achieved before reaching the highest stage, namely self-actualization. Reaching the stage of self-esteem, man must meet the physiological needs, sense of security, and love, thus significantly affecting each individual's self-acceptance of one's self-esteem, even in the hierarchy of Maslow's needs, he revealed that before achieving self-actualization, man must be able to meet previous needs. In achieving the need for love, here is reliable self-acceptance. When a man can love himself, he will also be able to appreciate himself.

Another study that also examined adolescents experiencing body shaming is the research of Herniyanti, Malfasari, and Hidayat (2019); the results of this study mentioned that shamming body behavior has a relationship with individual self-image. The more often a person becomes a victim of body shaming, the more negative his or her image. Herniyati et al. research (2019) does not discuss the impact of body shamming on other aspects. So in this study, the author 
added that self-acceptance also affects self-esteem and victims of body shaming itself. Furthermore, research conducted by Duarte (2017), body shamming behavior also affects the body's cognitive function significantly and not only affects self-esteem and self-acceptance.

\section{CONCLUSION}

Based on the results obtained, it can be concluded that there is a correlation or relationship between the variable of self-acceptance and the variable of self-esteem. This can be shown from correlation values of 0.553 and 0.403 in Spearman and Kendall's Tau correlation tests, where this substantial value indicates a coefficient of positive value and has a positive or consistent correlation. The hypothesis mentioned earlier is under the study results; this is obtained from the hypothesis test on the correlation test by obtaining a significance value of $<0.001$, which means that the hypothesis is acceptable. Then based on a simple linear analysis obtained the result that there is an influence between self-acceptance to self-esteem, also using the formula $t$ table and t count to test the hypothesis and the result is the same, the initial hypothesis can be accepted because the $\mathrm{t}$-table $<\mathrm{t}$-count is $2,041<5,487$.

\section{REFERENCES}

Andani, T. P. (2018). Hubungan penerimaan diri dan harga diri pada remaja dengan orang tua bercerai [Undergraduate thesis, Universitas Muhammadiyah Malang].

Chaplin, J. P. (2012). Kamus lengkap psikologi. RajaGrafindo Persada.

Duarte, C., \& Pinto-Gouveia, J. (2017). The impact of early shame memories in Binge Eating Disorder: The mediator effect of current body image shame and cognitive fusion. Psychiatry Research, 258, 511-517. https://doi.org/10.1016/j.psychres.2017.08.086

Heryana, A. 2020. Bahan ajar mata kuliah: Metodologi penelitian kuantitatif. Prodi Kesmas Universitas Esa Unggul.

Hidayat, R., Malfasari, E., \& Herniyanti, R. (2019). Hubungan perlakuan body shaming dengan citra diri mahasiswa. Jurnal Keperawatan Jiwa, 7(1), 79-86.

Hidayati, N. W. (2016). Hubungan harga diri dan konformitas teman sebaya dengan kenakalan remaja. Jurnal Penelitian Pendidikan Indonesia, 1(2), 31-36.

Kusmiran, E. 2014. Kesehatan reproduksi remaja dan wanita. Salemba Medika.

Oktaviani, M. A., 2019. Hubungan penerimaan diri dan harga diri pada remaja pengguna sosial media Instagram. Psikoborneo. 7(4), 549-556.

Papalia, D. E., Old, S. W., \& Feldman, R. D. (2011). Human development (Psikologi perkembangan). Kencana.

Priyatno, D. (2011). Buku saku SPSS. Media Kom.

Puspitasari, S. T., Tantiani, F. F., \& Wardhana, L. W. (2019). Upaya peningkatan baseline body acceptance melalui Gerakan Say No to Body Shaming di kalangan pelajar Kota Mojokerto. PLAKAT (Pelayanan Kepada Masyarakat), 1(2), 110-119. 
Rahayu, E. P. (2019). Dampak penerimaan pesan "body shamming" terhadap "self confidence" pada remaja perempuan di media sosial Instagram. Jurnal Commercium, 2(1), 78-82.

Ridha, M. (2012). Hubungan body image dengan penerimaan diri pada mahasiswa Aceh di Yogyakarta. Jurnal Empatby, 1(2), 1-5

Rinmalae, M. P., Regaletha, T. A., \& Benu, J. M. Y. (2019). Harga Diri dan Penerimaan Diri Remaja Akhir di Panti Asuhan Sonaf Maneka Kelurahan Lasiana Kota Kupang. Journal of Health and Behavioral Science, 1(4), 199-206.

Rusminingsih, E., Suciana, F., \& Wahyuningsih, N. (2020). Hubungan body shaming dengan interaksi sosial pada remaja perempuan di SMK Muhammadiyah 2 Klaten Utara. MOTORIK Jurnal Ilmu Kesehatan, 15(2), 47-51.

Sakinah, S. (2018). "Ini bukan lelucon": Body shaming, citra tubuh, dampak dan cara mengatasinya. Emik, 1(1), 53-67.

Solistiawati, A., \& Sitasari, N. W. Hubungan antara citra tubuh dengan harga diri remaja akhir putri (Studi pada mahasiswi reguler Universitas Esa Unggul). Jurnal Psikologi Esa Unggul, 13(01), 13-20.

Syafrizaldi, S., \& Pratiwi, S. (2020). Hubungan antara Lingkungan Sosial dengan Harga Diri Remaja Panti Asuhan Al Jam'iyatul Washliyah Binjai. Journal of Education, Humaniora and Social Sciences (JEHSS), 3(1), 193-199.

Vargas, E. (2019, September 11). Body-shaming: What is it \& why do we do it? https://www.waldeneatingdisorders.com/blog/body-shaming-what-is-it-why-do-we-doit/

Wahyuni, N. S., \& Auriella, A. (2021). Hubungan body image dengan harga diri pada remaja putri penggemar Kpop di Komunitas ARMY Medan. Journal of Education, Humaniora and Social Sciences (JEHSS), 3(3), 1365-1371.

Wangge, B. D. R., Hartini, N. (2013). Hubungan antara penerimaan diri dengan harga diri remaja pasca perceraian orang tua. Jurnal Psikologi Kepribadian dan Sosial, 2(1), 1-6.

Widiasti, N. L. R. (2016). Profil citra tubuh (body image) pada remaja dan implikasinya bagi bimbingan dan konseling (Studi deskriptif terhadap peserta didik kelas XI SMA Negeri 1 Sukaresmi Kabupaten Cianjur Tahun Ajaran 2015-2016) [Undergraduate thesis, Universitas Pendidikan Indonesia]. 